\title{
30 Years of Experience with Non-Hodgkin Lymphoma in Children and Adolescents: a retrospective cohort study
}

\author{
(iD) Maria Christina L. Oliveira ${ }^{1}$ \\ (iD) Keyla C. Sampaio ${ }^{1}$ \\ (iD) Andrea C. Brito ${ }^{1}$ \\ (D) Marcia K. Campos ${ }^{1}$ \\ (iD) Mitiko Murao ${ }^{1}$ \\ (iD) Rebeca Gusmão ${ }^{2}$ \\ DAna Angélica L. Fernandes ${ }^{2}$ \\ (iD) Marcos B. Viana ${ }^{1}$
}

1. Divisão de Hematologia Pediátrica, Departamento de Pediatria, Escola de Medicina, Universidade Federal de Minas Gerais, Belo Horizonte, MG, Brasil 2. Departamento de Pediatria, Escola de Medicina, Universidade Federal de Minas Gerais, Belo Horizonte, MG, Brasil

\section{SUMMARY}

OBJECTIVE: Describe the clinical and demographic characteristics of pediatric patients with non-Hodgkin's lymphoma (NHL) enrolled in a tertiary unit of Pediatric Hematology between 1982-2015.

PATIENTS AND METHODS: A retrospective cohort study of 140 patients aged 16 years or less with NHL. Demographic characteristics, data on diagnosis, and outcomes were analyzed. The overall survival (OS) analysis and stratification by the most frequent histological subtypes were performed using the Kaplan-Meier method.

RESULTS: One hundred and thirty-six patients with de novo NHL and four with NHL as a second malignancy were analyzed. The median age at diagnosis was 6.4 years (interquartile range, 4.2 to 11.1 years); 101 patients were males. Four patients had primary immunodeficiency, four had human immunodeficiency virus, two post-liver transplantation, and one had autoimmune lymphoproliferative syndrome. The most frequent histological type was NHL of mature B-cell (B-NHL-B; 67.1\%), with Burkitt's lymphoma being the most frequent subtype, and lymphoblastic lymphoma (LBL, 21.4\%). The main clinical manifestation at the diagnosis was abdominal tumors (41.4\%). During the follow-up time, 13 patients relapsed, but five of them reached a second remission. Thirty-five patients died, and 103 remained alive in clinical remission. No contact was possible for two patients. The OS at 5 years was $74.5 \%( \pm 3.8 \%)$. The OS estimated for patients with $L B L, N H L-B$, and the remaining was $80.4 \% \pm 7.9 \%, 72.8 \% \pm 4.7 \%$, and $74.5 \% \pm 17 \%$, respectively $(P=0.58)$.

CONCLUSION: Our results are comparable with cohorts from other middle-income countries.

KEYWORDS: Lymphoma, Non-Hodgkin. Child. Cohort Studies.

\section{INTRODUCTION}

In Brasil, a middle-income country (MIC), cancer is already the leading cause of death ( $8 \%$ of total) due to illness among children and adolescents aged 1 to 19 years. According to the Brasilian Institute of Cancer (INCA), it is expected that 12.5 thousand new cases of cancer in the pediatric population will be diagnosed

DATE OF SUBMISSION: 09-JUL-2019

DATE OF ACCEPTANCE: 29-Jul-2019

CORRESPONDING AUTHOR: Maria Christina Lopes A. Oliveira

Rua Engenheiro Amaro Lanari 389 /501 - Belo Horizonte, MG - Brasil - CEP 30310-580

Phone: 55 (31) 3564-5625

E-mail: chrismariana@gmail.com 
over the next years (http://www2.inca.gov.br). Lymphomas are the second most common cancer in Brazilian children, and non-Hodgkin lymphoma (NHL) is the most frequent histological type'.

For more than 30 years, the Division of Pediatric Hematology of the Hospital of Clinics of University Federal of Minas Gerais (HC-UFMG) has provided care to children and adolescents with $\mathrm{NHL}^{2,3}$. The HC-UFMG is located in Belo Horizonte, capital of the state of Minas Gerais, the third most populous municipality in the Southeastern region of Brasil ${ }^{4}$. As a tertiary care center, systematic data obtained during the clinical course of these patients is a rich source of knowledge to understand the outcome of NHL. The aim of this retrospective cohort study was to describe the main clinical characteristics and outcomes of 140 patients with NHL followed up at a single tertiary center in a MIC.

\section{METHODS}

Data were collected retrospectively from medical records of the Division of Pediatric Hematology Unit - HC-UFMG of 140 patients aged up to 16 years with NHL admitted between 1981 and 2015. Medical records were reviewed to collect demographic data (age, gender), clinical data (medical history, physical examination, clinical presentation), diagnostic procedures (imaging studies, bone marrow aspiration, cerebrospinal fluid - CSF analysis, tumor biopsy), disease staging, laboratory data (lactate dehydrogenase - LDH levels, blood counts, serum electrolytes, liver and kidney tests), treatment, and outcomes. All the diagnoses were confirmed by morphological and immunohistochemistry criteria defined by the World Health Organization (WHO) classification ${ }^{5}$. Immunohistochemistry was performed using monoclonal antibodies CD20, CD10, CD79a, CD30, CD3, CD15, TdT, CD45, and CD45RO for the detection of $\mathrm{B}$ and T cells. Cell lineage assignment required $50 \%$ or more of positive neoplastic B or T cells. Clinical staging was based on the St. Jude Children's Research Hospital staging system ${ }^{6}$. Central nervous system (CNS) disease was diagnosed by the presence of morphologically identifiable lymphoma cells (regardless of quantity) in CSF, an intracranial mass, or cranial nerve palsy not caused by an extradural mass.

Patients were treated according to their histological subtype: for lymphoblastic lymphoma (LBL), protocols based on ALL-type (acute lymphoblastic leukemia) strategy, for B-NHL (lymphoma non-Hodgkin of B- cell) and ALCL (anaplastic large cell lymphoma), short pulse-intensive chemotherapy ${ }^{7}$.

Complete remission (CR) was defined as the disappearance of all tumor masses confirmed by clinical examination and imaging investigations, approximately one month after the end of the treatment. Progression of the local tumor was defined if the tumor site showed no decrease in size after starting chemotherapy. Relapse was defined as the recurrence of lymphoma with the same histological or immunophenotype features as the initial one at any site after CR was achieved. Local relapse was diagnosed when it involved a previously involved site (except bone marrow and CSF).

The data were stored in a database developed for this specific purpose. Data analysis was descriptive and performed in the SPSS program. Data are reported as medians and interquartile range (IQ) or means and standard deviation (SD), when appropriate. Overall survival (OS) was defined as the time from diagnosis to the date of death due to any cause, or the date of last follow-up contact for patients who were alive. The OS was analyzed using the Kaplan-Meier method. OS analysis was performed stratified by the most frequent histological subtypes.

The study was approved by the Research Ethics Committee of UFMG.

\section{RESULTS}

\section{Patient characteristics}

The median age at diagnosis was 6.4 years (IQ range, 4.2 to 11.1). The diagnosis was based on the cytological examination of abdominal effusion in two patients, pleural effusion in five patients, and on tumor biopsies for the other cases. According to immunohistochemistry or immunophenotyping, 108 patients (77.1\%) had B-cell lineage neoplasia, 25 patients had T-cell, and 7 were indeterminate. Four patients had primary immunodeficiency (one with ataxia-telangiectasia), four acquired immunodeficiency syndrome (AIDS), two post-transplantation NHL, and one had autoimmune lymphoproliferative syndrome (ALPS). NHL arising in skin, bone, and liver were diagnosed in seven, four, and one patient, respectively. One patient diagnosed with cutaneous NHL had AIDS.

The most common histologic subtypes of NHL were mature B-cell (B-NHL) in 94 patients (67.1\%), including Burkitt' lymphoma (BL - 69 patients, 49.2\%), 
mature B-cell leukemia (B-AL, 6 patients), diffuse large B-cell lymphoma (DLBCL, 11patients), T-cell rich B-cell lymphoma (TCRBCL, 5 patients) and three undetermined. Thirty patients (21\%) were diagnosed with lymphoblastic lymphoma (LBL) and four with anaplastic large cell lymphoma (ALCL- 2- kinase - ALK-positive). The characteristics of these patients are summarized in Table 1.

Abdominal tumor, occurring in 58 patients (41.4\%), was the most common clinical presentation, followed by peripheral lymphadenopathy (32 patients, $22.9 \%$ ), mediastinal involvement (17 patients, 12.1\%), and face

TABLE 1. CLINICAL AND DEMOGRAPHIC CHARACTERISTICS OF 140 PATIENTS WITH NHL

\begin{tabular}{|c|c|}
\hline & $\mathrm{N}(\%)$ \\
\hline $\begin{array}{l}\text { Age of diagnosis (yr) } \\
\text { Median (IQ25-75) } \\
\text { Gender } \\
\text { Male } \\
\text { Female }\end{array}$ & $\begin{array}{c}6.4(4.2-11.1) \\
101(72.1) \\
39(27.9)\end{array}$ \\
\hline $\begin{array}{l}\text { Clinical presentation } \\
\text { Abdominal tumors } \\
\text { Peripheral lymphadenopathy } \\
\text { Mediastinal } \\
\text { Face } \\
\text { More than one site of involvement } \\
\text { Skin } \\
\text { Bone } \\
\text { Others } \\
\text { No information }\end{array}$ & $\begin{array}{l}58(41.4) \\
32(22.9) \\
17(12.1) \\
7(5.0) \\
5(4.2) \\
7(5.0) \\
4(2.9) \\
8(5.7) \\
2(1.4)\end{array}$ \\
\hline $\begin{array}{l}\text { Cell origin } \\
\text { B cell } \\
\text { T cell } \\
\text { Indeterminate }\end{array}$ & $\begin{array}{l}108(77.1) \\
25(17.9) \\
7(5.0)\end{array}$ \\
\hline $\begin{array}{l}\text { Histological type } \\
\text { B-NHL } \\
\text { Burkitt Lymphoma } \\
\text { Mature B-cell Acute Leukemia } \\
\text { Diffuse Large B-Cell Lymphoma } \\
\text { T-Cell rich B-Cell Lymphoma } \\
\text { Indeterminate } \\
\text { Lymphoblastic Lymphoma } \\
\text { B-LBL } \\
\text { T-LBL } \\
\text { Indeterminate } \\
\text { Anaplastic Large Cell Lymphoma } \\
\text { Cutaneous lymphoma* } \\
\text { Osseous lymphoma† } \\
\text { Hepatic lymphoma (indeterminate) }\end{array}$ & $\begin{array}{c}94(67.1) \\
69(49.2) \\
6(4.3) \\
11(7.9) \\
5(3.6) \\
3(2.1) \\
30(21.4) \\
7(5.0) \\
18(12.8) \\
5(3.6) \\
4(2.9) \\
7(5.0) \\
4(2.9) \\
1(0.7)\end{array}$ \\
\hline $\begin{array}{l}\text { Stage } \\
\text { Localized } \\
\text { Advanced } \\
\text { No information }\end{array}$ & $\begin{array}{c}35(25.0) \\
88(62.9) \\
17(12.1)\end{array}$ \\
\hline $\begin{array}{l}\text { Outcome } \\
\text { Alive in remission } \\
\text { In first remission } \\
\text { After relapsing } \\
\text { Death } \\
\text { Primary event } \\
\text { After relapsing } \\
\text { No information }\end{array}$ & $\begin{array}{c}103(73.6) \\
98(70.0) \\
5(3.6) \\
35(25.0) \\
27(19.3) \\
8(5.7) \\
2(1.4)\end{array}$ \\
\hline
\end{tabular}

(7 patients, 5\%). Other involved organs included the central nervous system (2), paravertebral mass (2), bone (4), skin (7), liver (1), and others (3). Five patients had more than one site of involvement: four had the involvement of the abdomen and thorax, and one had the involvement of the abdomen and paravertebral region. In two patients, no information on initial clinical manifestation had been recorded in clinical files. Most patients had advanced disease (88 patients, $62.9 \%)$.

\section{Outcome}

During the follow-up, 13 patients (9\%) relapsed, 35 $\operatorname{died}(25 \%)$, and $103(72 \%)$ remained alive in disease-free clinical remission. Two patients were not found for the follow-up (Table 1). The estimated OS for all patients was $74.5 \% \pm 3.8 \%$ (Figure 1). The likelihood of OS for patients with LBL, B-NHL, and other subtypes was $80.4 \% \pm 7.9 \%, 72.8 \% \pm 4.7 \%$, and $74.5 \% \pm 11 \%$, respectively ( $\mathrm{P}=0.58$; Figure 2).

\section{DISCUSSION}

NHL is a heterogeneous group of highly malignant tumors with a distinct pathological immune framework and clinical features ${ }^{8}$. In this retrospective cohort study, we evaluated the clinical outcome of 140 pediatric patients with NHL enrolled in a single tertiary center in a Southeastern region in Brasil.

The overall incidence of pediatric NHL is not accurately known. It comprises approximately $8-10 \%$ of all malignancies in children aged between five and 19 years, and it is more frequent in male adolescents ${ }^{8-10}$. The annual incidence per million inhabitants ranges from 5.9 in children younger than 5 years of age to about 10 in children between 5 and 14 years old, and 15 in adolescents ${ }^{10}$. It has been estimated that $90 \%$ of children diagnosed with NHL live in low-middle income countries (LMIC) ${ }^{11}$. In Brasil, NHL is also more prevalent among male pediatric patients'. In our study, NHL was about 2.5 times more frequent in boys.

The etiology of NHL is not well known. Like cancer in general, NHL probably arises from interactions between exogenous or endogenous exposures, genetic susceptibility, and chance ${ }^{12}$. On the other hand, it is well known that immunodeficiency, either primary or secondary, increases the risk of $\mathrm{NHL}^{10}$. Recently described is the association of interleukin IL-10 receptor deficiency with childhood B-NHL and the increased risk of NHL in the constitutional mismatch 
FIGURE 1. KAPLAN MEIER ESTIMATES THE PROBABILITY OF OVERALL SURVIVAL AMONG 140 CHILDREN AND ADOLESCENTS WITH NHL.

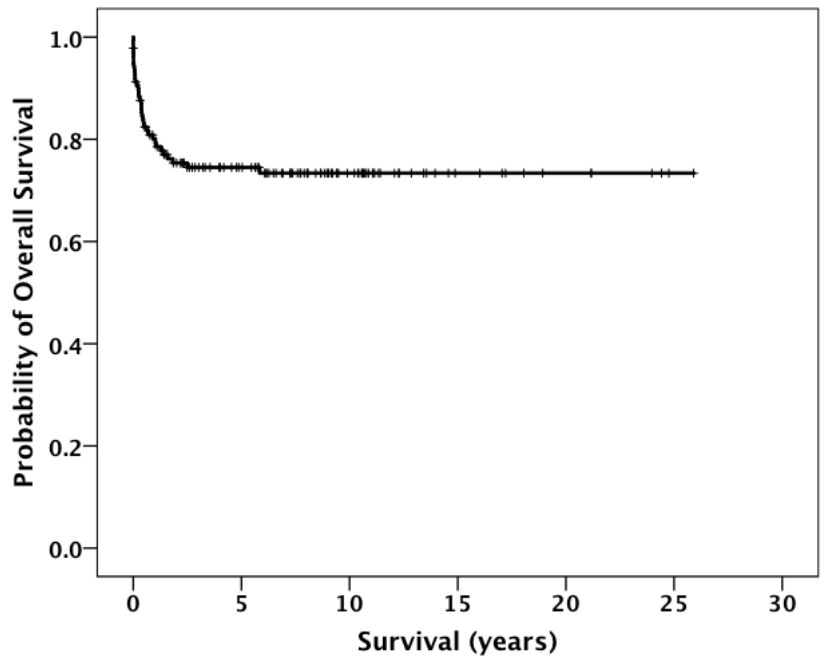

repair deficiency syndrome ${ }^{13}$. In the present cohort, the majority of patients were immunocompetent, and only $11(8 \%)$ had immunosuppression or immunodeficiency-related NHL.

There have been scarce studies concerning the association between race/ethnicity and the incidence of pediatric NHL. The Pediatric Health Information System (USA) reported that NHL is almost twice as common in whites compared to African Americans ${ }^{14}$. Brazilians constitute a trihybrid population with European, African, and Amerindian roots. In the population of the state of Minas Gerais, where the present study was conducted, European-African interbreeding occurred very intensely ${ }^{15}$. In Brasil, differences in NHL incidence by race/ethnicity are not reported.

The major histologic subtype of NHL in high-income countries (HIC) is Burkitt lymphoma (BL, 40\%), followed by lymphoblastic lymphoma (LBL, 25\%), diffuse large B-cell lymphoma (LDGCB- 10\%), and anaplastic large cell lymphoma (ALCL,10\%) Egypt, Nicaragua, Brasil, and tropical Africa, BL is also the most frequent subtype of NHL ${ }^{1,11}$. In contrast, in India, T-LBL is the most common NHL subtype $(32 \%)^{16}$. In the present study, $67 \%$ of cases of NHL had B-cell origin, and BL was the most common subtype of NHL, as emphasized in the literature. The predominance of BL (49.2\%) was also reported by another Brasilian study conducted in the Northeastern region of Brasil ${ }^{17}$. In the present cohort, the median age at diagnose was lower than in $\mathrm{HIC}^{9}$. The median age at presentation of NHL in children in HIC is 10 years, while in our cohort, it was about six years.
FIGURE 2. KAPLAN MEIER ESTIMATES THE PROBABILITY OF OVERALL SURVIVAL STRATIFIED ACCORDING TO THE HISTOLOGICAL SUBTYPES.

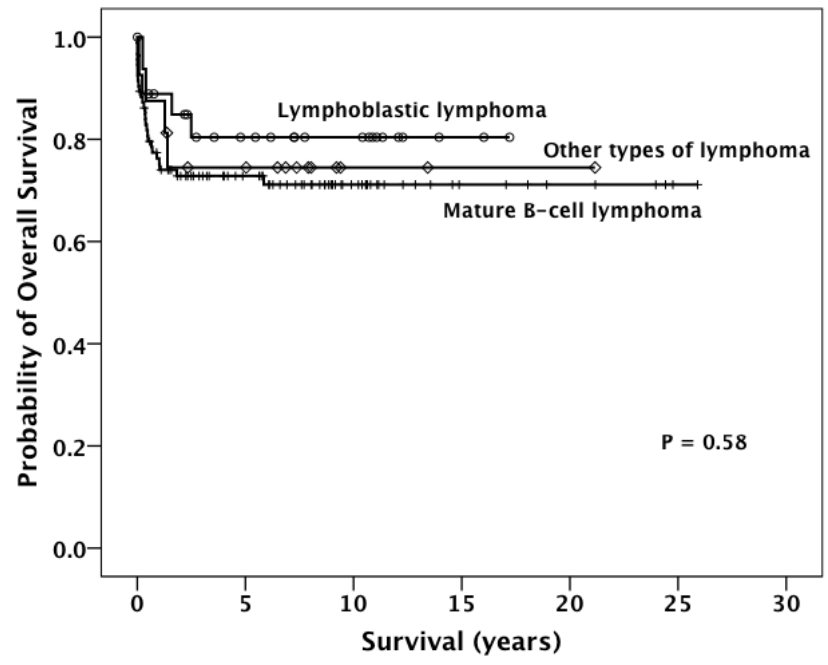

As reported in a study of cancer survivors diagnosed in childhood and adolescence, NHL as a secondary neoplasm (SN) is rare and information on characteristics and outcomes of these patients are scarce $^{\mathbf{1 8}}$. In the present study, only four patients were diagnosed with NHL following previous cancers other than NHL. In all patients, the first cancer was a lymphoid neoplasm.

The clinical features of NHL in children are characterized mostly by extranodal involvement and are related to the histological type. The abdominal tumor was the most frequent feature in our patients, reflecting the very high incidence of BL. This clinical manifestation is also the most frequent in the USA among children with BL. In Africa, where BL is endemic, tumors in the jaw or around the eyes are more common $^{19}$. Conversely, NHL arising in sites like bone, skin, and liver is unusual and has been reported in approximately $7 \%$ of all NHL pediatric patients ${ }^{20,21}$. In the present series, only 12 patients (8.6\%) exhibited an involvement of these less common sites at the time of the initial diagnosis. Regarding CNS involvement, the exact incidence is unknown. In a study by Salzburg et al., ${ }^{22} 6 \%$ of patients with NHL were CNS positive, and the most frequent subtypes of NHL were BL/ B-AL. In our study, only $1.4 \%$ of patients were CNS positive, and both had BL.

NHL is considered one of the neoplasms with the best chance of cure in children, although it is almost exclusively a high-grade malignancy with disseminated disease at diagnosis ${ }^{9}$. Currently, depending on the histological type, most patients in HIC can be cured by risk-adapted chemotherapy and supportive 
care $^{23}$. This modern chemotherapy requires supportive care to face life-threatening toxicities, sometimes unavailable in several LMIC. While the estimated 5-year survival rate ranges from approximately 70\% to $>95 \%$, depending on stage and histology in HIC, in LMIC, the overall survival is less than $50 \%{ }^{9,11}$. This discrepancy between LMIC and HIC has been attributed to several problems such as later diagnosis, misdiagnosis, pathology capacity, poor clinical status of the patient at diagnosis, the non-adherence to treatment, unavailability of some active drugs, and inadequate supportive care. In the present cohort, the probability of 5-year OS for 140 patients with NHL was $74.5 \%$ $( \pm 3.8 \%)$, which is comparable to those reported in other middle-income countries. Regarding the most frequent histological types in the present cohort, we did not detect a statistically significant difference of OS between those with LBL and B- NHL when compared with the other patients. Interestingly, by inspecting the Kaplan-Meier plots concerning OS, we can observe that there was a sharp drop within the first two years after the diagnosis. Of note, patients who survived this period did not present any events thereafter. This possibly means that a delayed referral may play a substantial role in the worse prognosis in our cohort once patients could be admitted in worse clinical conditions.

For patients who experience relapse, the prognosis is clearly worse and differs according to the NHL subtype. Patients with relapsed ALCL or DLBCL have a fair chance to survive (40-60\%), whereas the survival of patients with relapsed BL and LBL is less than $30 \%{ }^{24}$. In the present cohort, 13 patients relapsed, and eight of them (61.5\%) died.

Although the present study has a significant number of patients, it has some limitations that deserve mention. The major limitation are issues inherent to all retrospective cohort studies, in which some clinically important details may be unavailable. The limited number of some histologic types of NHL (DLBCL, ALCL) and NHL arising in unusual sites in our cohort lead to insufficient power to draw definitive conclusions. On the other hand, the diagnoses of rare subtypes such as TCRBCL can be attributed to better training with diagnostic procedures. Despite these limitations, our study was carried out by the same medical team in a single institution with long follow-up time. The adherence to treatment of patients and their families was impressive for a MIC region.

\section{CONCLUSION}

In conclusion, our results can contribute to the understanding of the epidemiology and clinical course of pediatric NHL in Brasil. The clinical features and survival rates in the cohort are comparable with those from other middle-income countries. Our findings suggest that a timely referral might contribute to a better prognosis for these patients. Further collaborative prospective studies are obviously necessary to establish the best interventions for children with NHL in middle-income countries and to develop strategies to facilitate the access of patients to the health service, reducing the early mortality related to NHL.

\section{Disclosure}

The authors declare no conflicts of interest.

\section{Acknowledgments}

M.C.L.O is supported by a CAPES grant 2767-15-5. R.G. and A.A.L.F. received grants from FAPEMIG.

\section{Authors' Contributions}

Conception and study design: MCLO, MBV; data acquisition: KCS,ACB,MKC,MM,RG, AALF; data analysis/interpretation: MCLO, KCS,ACB,MKC,MM,MBV; statistical analysis: MCLO, supervision or mentorship: MCLO, MBV. Each author contributed with important intellectual content during the manuscript drafting or revision and accepted accountability for the overall work by ensuring that questions pertaining to the accuracy or integrity of any portion of the work are appropriately investigated and resolved. MCLO takes responsibility that this study has been reported honestly, accurately, and transparently and that no important aspects of the study have been omitted. 


\section{RESUMO}

OBJETIVO: Descrever as características clínicas e demográficas de pacientes pediátricos com linfoma não Hodgkin (LNH) em uma unidade terciária de Hematologia Pediátrica entre 1982-2015.

PACIENTES E MÉTODOS: Estudo de coorte retrospectivo de dados de prontuários de 140 pacientes com idade até 16 anos com LNH. Características demográficas e dados relativos ao diagnóstico e evolução foram analisados. A sobrevida global (SG) e estratificada pelos subtipos histológicos mais frequentes foi analisada pelo método de Kaplan-Meier.

RESULTADOS: Dados de 136 pacientes com LNH de novo e quatro com LNH como segunda neoplasia foram analisados. A mediana de idade ao diagnóstico foi 6,4 anos (intervalo interquartil: 4,2 a 11,1 anos); 101 pacientes eram meninos. Onze pacientes apresentavam imunodeficiência (quatro primária, quatro secundária ao vírus da imunodeficiência humana adquirida, dois pós-transplante hepático e um com síndrome linfoproliferativa autoimune). Os tipos histológicos mais frequentes foram o LNH de células B madura (LNH-B, $67,1 \%$ dos pacientes), sendo o linfoma de Burkitt o subtipo mais frequente, e o linfoma linfoblástico (LL, 21,4\%). A principal manifestação clínica ao diagnóstico foi massa abdominal (41,4\%). A mediana de seguimento dos sobreviventes foi 7,7 anos (intervalo interquartil: 3,3 a 10,9 anos). Treze pacientes recidivaram (cinco alcançaram segunda remissão clínica), 35 faleceram, 103 permanecem vivos em remissão completa e dois perderam o seguimento. A probabilidade de $S G$ em cinco anos foi $74,5 \% \pm 3,8 \%$. Para os pacientes com $L L$, LNH-B e os demais, a $S G$ foi $80,4 \% \pm 7,9 \%, 72,8 \% \pm 4,7 \%$ e $74,5 \% \pm 11 \%$, respectivamente $(P=0,58)$.

CONCLUSÃo: Nossos resultados são comparáveis aos de outros países de renda média.

PALAVRAS-CHAVE: Linfoma não Hodgkin. Criança. Estudos de coortes.

\section{REFERENCES}

1. Ferreira JM, Klumb CE, Souza Reis R, Oliveira Santos M, Oliveira JF, Camargo $B$, et al. Lymphoma subtype incidence rates in children and adolescents: first report from Brasil. Cancer Epidemiol. 2012;36(4):e221-6.

2. Cunha KC, Oliveira MC, Gomes AC, Castro LP, Viana MB. Clinical course and prognostic factors of children with Burkitt's lymphoma in a developing country: the experience of a single centre in Brasil. Rev Bras Hematol Hemoter. 2012;34(5):361-6.

3. Oliveira MC, Sampaio KC, Oliveira AC, Santos AD, Castro LP, Viana MB. Outcome of children and adolescents with lymphoblastic lymphoma. Rev Assoc Med Bras. 2016;62(1):59-64

4. Censo 2016. Brasilian Institute of Geography and Statistics, 2016. 2018. [cited Jun 13]. 2019 Available from: http://www.ibge.gov.br/home/estatistica/ populacao/censo2000/populacao/cor_raca_Censo2000.pdf.)

5. Swerdlow SH. Lymphoma classification and the tools of our trade: an introduction to the 2012 USCAP Long Course. Mod Pathol. 2013;26(Suppl 1):S1-S14.

6. Murphy SB. Classification, staging and end results of treatment of childhood non- Hodgkin's lymphomas: dissimilarities from lymphomas in adults. Semin Oncol. 1980;7(3):332-9.

7. Woessmann W, Seidemann K, Mann G, Zimmermann M, Burkhardt B, Oschlies I, et al; BFM Group. The impact of the methotrexate administration schedule and dose in the treatment of children and adolescents with B-cell neoplasms: a report of the BFM Group Study NHL-BFM95. Blood. 2005;105(3):948-58

8. Cairo MS, Raetz E, Lim MS, Davenport V, Perkins SL. Childhood and adolescent non-Hodgkin lymphoma: new insights in biology and critical challenges for the future. Pediatr Blood Cancer. 2005;45(6):753-69.

9. Bollard CM, Lim MS, Gross TG; COG Non-Hodgkin Lymphoma Committee. Children's Oncology Group's 2013 blueprint for research: non-Hodgkin lymphoma. Pediatr Blood Cancer. 2013;60(6):979-84.

10. Minard-Colin V, Brugières L, Reiter A, Cairo MS, Gross TG, Woessmann $W$, et al. Non-Hodgkin lymphoma in children and adolescents: progress through effective collaboration, current knowledge, and challenges ahead. | Clin Oncol. 2015;33(27):2963-74.

11. Gross TG, Biondi A. Paediatric non-Hodgkin lymphoma in low and middle income countries. Br J Haematol. 2016;173(4):651-4.

12. Inaba H, Greaves M, Mullighan CG. Acute lymphoblastic leukaemia. Lancet. 2013;381(9881):1943-55.
13. Neven B, Mamessier E, Bruneau|, Kaltenbach S, Kotlarz D Suarez F et al. A Mendelian predisposition to B-cell lymphoma caused by IL-10R deficiency. Blood. 2013;122:(23):3713-22

14. Citrin R, Horowitz IP, Reilly AF, Li Y, Huang YS, Getz KD, et al. Creation of a pediatric mature B-cell non-Hodgkin lymphoma cohort within the Pediatric Health Information System Database. PLoS One. 2017;12(10):e0186960.

15. Parra FC, Amado RC, Lambertucci JR, Rocha J, Antunes CM, Pena SD. Color and genomic ancestry in Brasilians. Proc Natl Acad Sci U S A. 2003;100(1):177-82

16. Naresh KN, Srinivas $V$, Soman CS. Distribution of various subtypes of non-Hodgkin's lymphoma in India: a study of 2773 lymphomas using R.E.A.L. and WHO Classifications. Ann Oncol. 2000;11(Suppl 1):63-7.

17. Pedrosa MF, Pedrosa F, Lins MM, Pontes Neto NT, Falbo GH. Non-Hodgkin's lymphoma in childhood: clinical and epidemiological characteristics and survival analysis at a single center in Northeast Brasil. . Pediatr (Rio J). 2007;83(6):547-54.

18. Landmann E, Oschlies I, Zimmermann M, Moser O, Graf N, Suttorp M, et al; Berlin-Frankfurt-Münster group. Secondary non-Hodgkin lymphoma $(\mathrm{NHL})$ in children and adolescents after childhood cancer other than NHL. $\mathrm{Br}$ | Haematol. 2008;143(3):387-94.

19. Ward E, DeSantis C, Robbins A, Kohler B, lemal A. Childhood and adolescent cancer statistics, 2014. CA Cancer | Clin. 2014;64(2):83-103.

20. Oliveira MC, Pereira LB, Rodrigues PC, Sampaio KC, Oliveira BM, Viana MB. Initial cutaneous manifestation of lymphomas in children. An Bras Dermatol. 2011;86(4):799-802

21. O'Suoji C, Welch |l, Perkins SL, Smith LM, Weitzman S, Simko SI, et al. Rare pediatric non-Hodgkin lymphomas: a report from children's oncology group study ANHL 04B1. Pediatr Blood Cancer. 2016;63(5):794-800.

22. Salzburg J, Burkhardt B, Zimmermann M, Wachowski O, Woessmann W, Oschlies I, et al. Prevalence, clinical pattern, and outcome of CNS involvement in childhood and adolescent non-Hodgkin's lymphoma differ by non-Hodgkin's lymphoma subtype: a Berlin-Frankfurt-Munster Group Report. J Clin Oncol. 2007;25(25):3915-22.

23. Reiter A. Diagnosis and treatment of childhood non-hodgkin lymphoma. Hematology Am Soc Hematol Educ Program. 2007:285-96.

24. Woessmann W. XI. How to treat children and adolescents with relapsed non-Hodgkin lymphoma? Hematol Oncol. 2013;31(Suppl 1):64-8. 